\title{
GAMBARAN RESIKO KARIES GIGI PADA MAHASISWA ANGKATAN 2008 DI PROGRAM STUDI PENDIDIKAN DOKTER GIGI FAKULTAS KEDOKTERAN UNSRAT DENGAN MENGGUNAKAN KARIOGRAM
}

\author{
${ }^{1}$ Roden Kawung \\ ${ }^{2}$ Dinar Wicaksono \\ ${ }^{2}$ Joenda S. Soewantoro
}

\author{
${ }^{1}$ Kandidat Skripsi Program Studi Pendidikan Dokter Gigi Fakultas Kedokteran \\ Universitas Sam Ratulangi Manado \\ ${ }^{2}$ Program Studi Pendidikan Dokter Gigi Fakultas Kedokteran Universitas Sam Ratulangi
}

\begin{abstract}
The risk of caries is an opportunity for someone to have some caries lesions over time. Caries risk is not the same on every person and not last forever because it can be changed if patients take the precautions either by himself or dentist. Caries risk measurement is needed in order to take preventive measures directed against people who have a high risk of caries. This study was conducted to determine the percentage level of caries risk in students of Dentistry on Medicine faculty class of 2008 Sam Ratulangi University. This research is a descriptive study. Sampling using simple random sampling method, the 52 students of the 110 students who meet the criteria of the sampling frame. Samples were randomly selected to meet the specified number of samples. The informations were collected by interview using a questionnaire, while the examination of caries experience (DMFT), scores of plaque, saliva secretion and buffer capacity is done using the sonde, mouth mirror, disclosing solution, and a $\mathrm{pH}$ indicator. The results of the research students of Dentistry on Medicine faculty class of 2008 Sam Ratulangi University showed that all respondents have a low risk of dental caries and there is no respondents indicating a high risk of dental caries. However, students of Dentistry on Medicine faculty class of 2008 Sam Ratulangi University are expected to keep on the diet by eating snacks with low carbohydrate content with a maximum frequency of 3 times a day and use a regular fluoride program to reduce caries risk factors.
\end{abstract}

Keywords: Caries risk, Cariogram.

\begin{abstract}
Abstrak: Risiko karies merupakan peluang seseorang untuk mempunyai beberapa lesi karies selama kurun waktu tertentu. Risiko karies pada setiap orang tidak sama dan tidak tetap seumur hidup oleh karena hal ini dapat berubah apabila pasien melakukan tindakan pencegahan baik oleh dirinya sendiri maupun dokter gigi. Pengukuran risiko karies diperlukan agar dapat melakukan tindakan pencegahan yang ditujukan langsung kepada orang yang mempunyai risiko tinggi terhadap karies. Penelitian ini dilakukan untuk mengetahui tingkat persentase risiko karies pada mahasiswa Program Studi pendidikan Dokter Gigi Fakultas Kedokteran Universitas Sam Ratulangi Manado angkatan 2008. Jenis penelitian ini adalah penelitian deskriptif. Pengambilan sampel menggunakan metode simple random sampling, yaitu 52 orang mahasiswa dari 110 orang mahasiswa yang memenuhi kriteria sampling frame. Sampel dipilih secara acak hingga memenuhi jumlah sampel yang ditentukan. Pengumpulan data dilakukan dengan wawancara menggunakan kuesioner sedangkan pemeriksaan pengalaman karies (DMFT), skor plak, sekresi saliva dan kapasitas buffer dilakukan menggunakan sonde, kaca mulut, disclosing solution, dan $\mathrm{pH}$ indikator. Hasil penelitian mahasiswa Program Studi pendidikan Dokter Gigi Fakultas Kedokteran Universitas Sam Ratulangi Manado angkatan 2008 menunjukan bahwa seluruh responden memiliki resiko karies gigi yang rendah dan tidak ada responden yang menunjukkan resiko karies gigi yang tinggi. Namun demikian, mahasiswa Program Studi pendidikan Dokter Gigi Fakultas Kedokteran Universitas Sam Ratulangi Manado angkatan 2008 diharapkan mengupayakan dalam menjaga pola makan dengan mengonsumsi jajanan dengan kandungan karbohidrat rendah dengan frekuensi maksimal 3 kali sehari dan penggunaan program fluor yang rutin untuk mengurangi faktor risiko karies.
\end{abstract}

Kata kunci: Resiko Karies, Kariogram. 
Sehat memang merupakan sesuatu yang sangat mahal terutama bila sudah jatuh sakit. Sehat merupakan bagian dari kualitas hidup, oleh karena itu sehat tidak hanya berarti sehat secara fisik saja tetapi juga harus sehat mental dan kehidupan sosialnya. Secara umum, seseorang dikatakan sehat tidak hanya tubuhnya saja yang sehat tetapi juga sehat rongga mulut dan giginya. Gigi yang sehat juga tidak cukup hanya rapi dan putih saja tetapi harus didukung oleh gusi, akar dan tulang pendukung yang sehat.

Prevalensi karies gigi telah mengalami penurunan selama beberapa tahun di banyak negara. Hal ini dapat dilihat dari hasil pengukuran indeks karies yang lebih kecil di negara-negara maju. Namun studi epidemologi yang ada menunjukkan bahwa distribusi karies gigi tidak sama di setiap negara; di negara berkembang seperti Indonesia, indeks karies cenderung meningkat sebagai akibat kurangnya pemeliharaan gigi. ${ }^{1}$

Gigi akan berfungsi dengan baik apabila gigi tersebut dalam keadaan sehat, sebaliknya gigi dan mulut yang tidak sehat akan menimbulkan masalah. Sampai sekarang, karies merupakan masalah kesehatan gigi dan mulut yang masih memerlukan perhatian serius. Walaupun prevalensi penyakit gigi ini dilaporkan sudah menurun di beberapa negara, namun prevalensinya di Indonesia masih cukup tinggi.

Laporan hasil Riset Kesehatan Dasar (RISKESDAS) tahun 2007 menyebutkan bahwa prevalensi rata-rata penduduk Indonesia bermasalah gigi dan mulut sebesar 23,4\%, dimana prevalensi karies melalui pemeriksaan DMF-T untuk rata-rata nasional sebesar 4,85\% yang berarti ratarata penduduk Indonesia telah mengalami kerusakan gigi sebanyak 5 buah gigi per orang, sedangkan untuk provinsi Sulawesi Utara prevalensi karies adalah sebesar $5,01 \%$ diatas nilai rata-rata nasional. ${ }^{2}$

Tingginya karies di Indonesia masih belum mendapatkan penanganan yang signifikan. ${ }^{3}$ Beberapa upaya telah dilakukan untuk mengurangi prevalensi karies gigi, di antaranya dengan melakukan pengukuran resiko karies. Resiko karies adalah peluang seseorang untuk mempunyai beberapa lesi karies selama kurun waktu tertentu. Pengukuran resiko karies dilakukan agar tindakan pencegahan dapat ditujukan langsung kepada orang yang mempunyai resiko tinggi terhadap karies. ${ }^{1}$

Dewasa ini, telah dikembangkan teknik pengukuran resiko karies dengan menggunakan Kariogram yang diperkenalkan oleh Dr. Bratthal. Pengukuran resiko karies pada mahasiswa angkatan 2008 diProgram Studi Pendidikan Dokter Gigi Fakultas KedokteranUniversitas Sam Ratulangi Manado ( PSPDG FK UNSRAT) perlu dilakukan karena sebagai calon dokter gigi penting untuk dapat meningkatkan kemampuan dalam menurunkan resiko karies dan selama ini belum pernah ada penelitian mengenai penggunaan Kariogram untuk mengetahui resiko karies pada mahasiswa.Gambaran resiko karies gigi pada mahasiswa angkatan 2008 di PSPDG FK UNSRAT dapat dengan mudah diukur dengan menggunakan Kariogram,dan juga penggunaan Kariogram praktis dan tidak banyak biaya.

\section{METODE}

Jenis penelitian ini ialah penelitian deskriptif. Penelitian ini dilaksanakan di ruangan perkuliahan dan di tempat tinggal mahasiswa PSPDG FK UNSRAT pada bulan Desember 2011 - Januari 2012. Populasi pada penelitian ini yaitu mahasiswa PSPDG FK UNSRAT angkatan 2008 yang berjumlah 110 orang mahasiswa, kemudianmenggunakan rumus Slovin diperoleh sampel minimum sebanyak 52 orang mahasiswa.

Variabel yang diteliti pada penelitian ini yaitu jenis kelamin, pemeriksaan resiko kariesdisesuikan dengan variabel yang terdapat pada Kariogram. Pengalaman karies digunakan untuk mengukur derajat keparahan karies digunakan DMF-T (Decayed, Missing, Filled Teeth). Dengan kategori DMF-T menurut WHO (0$1,1=$ Rendah, skor $0 ; 1,2-2,6=$ Sedang, skor 1 ; 2,7-4,4=Tinggi, skor 2; $>4,5=$ Sangat tinggi, skor 3$){ }^{4}$ 
Kawung, Wicaksono, Soewantoro; Gambaran Resiko Karies Gigi pada Mahasiswa...

Skor plak diukur memakai indeks Löe and Silness yang dimodifikasi (Skor $0=$ tidak dijumpai adanya plak, $<0,4$; Skor $1=$ dijumpai lapisan tipis plak yang tidak lebih dari sepertiga permukaan gigi, 0,4-1,0; Skor $2=$ dijumpai lapisan tipis plak yang lebih dari sepertiga permukaan gigi tetapi belum sampai duapertiga permukaan gigi, 1,1-2,0; Skor 3=dijumpai lapisan tipis plak yang lebih dari duapertiga permukaan gigi, $>2,0){ }^{4}$

Pengukuran Sekresi saliva menggunakan gelas ukur mL selama 1 menit. Kemudian peneliti mencatat volume saliva pada gelas ukur mL.Skor $0=$ Sekresi saliva normal $>1,1 \mathrm{ml} /$ menit, skor $1=$ Sekresi saliva rendah dari 0,9 $-1,1 \mathrm{ml} /$ menit, skor $2=$ Sekresi saliva lebih rendah dari 0,5-0,9 ml / menit, skor $3=$ Sekresi saliva sangat rendah, xerostomia, $<0,5 \mathrm{ml} /$ menit. $^{4}$

Kapasitas buffer berdasarkan $\mathrm{pH}$, perkiraanasam, basa dan netralnya saliva pada mahasiswa yang diukur dengan memasukkan $\mathrm{pH}$ indikator ke dalam saliva mahasiswa pada gelas ukur $\mathrm{mL}$ selama 3 detik. Kemudian peneliti menyesuaikan warna pada $\mathrm{pH}$ indikator. ${ }^{4}$

Kandungan makanan dengan kandungan karbohidrat yang rendah sedang, tinggi, dan sangat tinggi [bobot:Nilai 1= Kandungan karbohidrat rendah (susu coklat, pecel, gado-gado, rujak), Nilai $2=$ Kandungan karbohidrat sedang nilai (bakso, gorengan, kerupuk), Nilai 3= Kandungan karbohidrat tinggi (teh manis, manisan,minuman berkarbonasi(softdrink), roti), Nilai 4= Kandungan karbohidrat sangat tinggi (sirup, permen, coklat, es krim coklat)], Skor = jumlah nilai makanan (Skor $0=$ Kandungan karbohidrat rendah nilai $3-5$, skor $1=$ Kandungan karbohidrat sedang nilai 6-9, skor 2= Kandungan karbohidrat tinggi nilai 9-12, skor 3= Kandungan karbohidrat sangat tinggi nilai di atas 12). ${ }^{4}$

Frekuensi jajan dalam sehari.Skor $0=$ Frekuensi jajan maksimal 3 kali sehari (24jam), skor $1=$ Frekuensi jajan 4 - 5 kali sehari (24jam), skor 2= Frekuensi jajan 6 - 7 kali sehari (24jam), skor 3= Frekuensi jajan $>7$ kali sehari (24jam). ${ }^{4}$

Penggunaan fluor, frekuensi dan bentuk aplikasi fluor.Skor $0=$ mendapatkan fluoride dari pemakaian pasta gigi rutin dan sering berkumur-kumur dengan larutan yang mengandung fluor, skor $1=$ mendapatkan fluoride dari pemakaian pasta gigi rutin dan jarang berkumurkumur dengan larutan yang mengandung fluor, skor $2=$ hanya mendapatkan fluor dari pemakaian pasta gigi, skor $3=$ tidak pernah menggunakan pasta gigi dan tidak pernah berkumur-kumur dengan larutan yang mengandung fluoride. Untuk data kandungan jajanan, frekuensi jajan, dan pemakaian fluor, datadiperoleh dari pengisian kuesioner.

Kategori pengukuran resiko karies pada Kariogrammenjadi 3 kategori, yaituresiko rendah, sektor hijau $>75 \%$, resiko sedang, sektor hijau= 25\%-75\%, resiko tinggi, sektor hijau $<25 \%$.

\section{HASIL PENELITIAN}

Dari 52 orang responden, persentase responden perempuan: 55,8\%, dan laki-laki: 44,2\%.Skor DMFT pada keseluruhan responden rendah yaitu $<1,1$. Dalam parameter Kariogram dikelompokkan pada kategori rendah (Tabel 1).

Tabel 1. Persentase Kategori pengalaman karies gigi

\begin{tabular}{cccc}
\hline Skor & Pengalaman Karies & n & \% \\
\hline 0 & Rendah & 52 & 100 \\
1 & Sedang & 0 & 0 \\
2 & Tinggi & 0 & 0 \\
3 & Sangat tinggi & 0 & 0 \\
Total & & 52 & 100 \\
\hline
\end{tabular}

Hanya 11,5\% responden mengonsumsi kandungan jajanan dengan karbohidrat rendah (Tabel 2).

Tabel 2. Persentase kategori kandungan jajanan

\begin{tabular}{cccc}
\hline Skor & Kandungan jajanan & $\mathbf{n}$ & $\mathbf{\%}$ \\
\hline 0 & Rendah & 6 & 11,5 \\
1 & Sedang & 10 & 19,2 \\
2 & Tinggi & 17 & 32,7 \\
3 & Sangat tinggi & 19 & 36,6 \\
Total & & 52 & 100 \\
\hline
\end{tabular}


Jurnal e-GiGi (eG), Volume 2, Nomor 2, Juli-Desember 2014

Hampir keseluruhan responden mengonsumsi makanan dengan frekuensi maksimal tiga kali sehari dengan persentase $78,8 \%$ yang termasuk kategori rendah. Hanya 21,2\% responden dengan frekuensi jajan 4-5 kali sehari. Tidak ada seorangpun responden dengan frekuensi $>5$ kali sehari (Tabel 3).

Tabel 3. Persentase kategori frekuensi jajan

\begin{tabular}{cccc}
\hline Skor & Frekuensi jajan & $\mathbf{n}$ & $\mathbf{\%}$ \\
\hline 0 & Rendah & 41 & 78,8 \\
1 & Sedang & 11 & 21,2 \\
2 & Tinggi & 0 & 0 \\
3 & Sangat tinggi & 0 & 0 \\
Total & & 52 & 100 \\
\hline
\end{tabular}

Tidak ada responden yang memiliki indeks plak yang kurang baik ataupun indeks plak yang buruk (Tabel 4).

Tabel 4. Persentase kategori indeks plak

\begin{tabular}{cccc}
\hline Skor & Indeks plak & n & \% \\
\hline 0 & Sangat baik, PI $=<0,4$ & 15 & 28,8 \\
1 & Baik, PI = 0,4 - 1,0 & 37 & 71,2 \\
2 & Kurang baik, PI = 1,1-2,0 & 0 & 0 \\
3 & Buruk, PI $=>2,0$ & 0 & 0 \\
Total & & 52 & 100 \\
\hline
\end{tabular}

Keseluruhan responden mempunyai kapasitas buffer dengan $\mathrm{pH}$ normal, yaitu $\mathrm{pH} \geq 6,0$. Tidak ada responden yang mempunyai kapasitas buffer dengan $\mathrm{pH}$ sedang $(4,5-5,5)$ atau rendah $(\leq 4,0)($ Tabel 5$)$.

Tabel 5. Persentase kapasitas buffer saliva

\begin{tabular}{cccc}
\hline Skor & Kapasitas buffer & n & $\mathbf{\%}$ \\
\hline 0 & Normal / baik, $\mathrm{pH} \geq 6,0$ & 52 & 100 \\
1 & Sedang / kurang baik, $\mathrm{pH}=$ & 0 & 0 \\
& $4,5-5,5$ & & \\
2 & Rendah, $\mathrm{pH} \leq 4,0$ & 0 & 0 \\
Total & & 52 & 100 \\
\hline
\end{tabular}

Keseluruhan responden memiliki skor sekresi saliva Normal $>1,1 \mathrm{ml} /$ menit (Tabel 6).

Tabel 6. Persentase kategori sekresi saliva

\begin{tabular}{|c|c|c|c|}
\hline Skor & Sekresi saliva & $\mathbf{n}$ & $\%$ \\
\hline 0 & Normal, > 1,1 ml/menit & 52 & 100 \\
\hline 1 & Sedang, 0,9-1,1 ml/menit & 0 & 0 \\
\hline 2 & Rendah, 0,5 - 0,9 ml/menit & 0 & 0 \\
\hline 3 & $\begin{array}{c}\text { Sangat rendah, }<0,5 \\
\mathrm{ml} / \mathrm{menit}\end{array}$ & 0 & 0 \\
\hline Total & & 52 & 100 \\
\hline \multicolumn{4}{|c|}{$\begin{array}{l}\text { Sebagian besar responden hanya } \\
\text { nggunakan pasta gigi yang mengandung } \\
\text { pride, yaitu sebanyak 88,5\% dan hanya } \\
5 \% \text { responden yang rutin menggunakan } \\
\text { ta gigi yang mengandung fluoride dan } \\
\text { nur larutan yang mengandung fluoride } \\
\text { bel 7). }\end{array}$} \\
\hline
\end{tabular}

Tabel 7. Persentase kategori penggunaan fluor

\begin{tabular}{clcc}
\hline Skor & \multicolumn{1}{c}{ Program fluoride } & n & \% \\
\hline 0 & $\begin{array}{l}\text { Rutin menggunakan pasta } \\
\text { gigi yang mengandung }\end{array}$ & 11,5 \\
& $\begin{array}{l}\text { fluoride \& kumur larutan } \\
\text { yang mengandung fluoride }\end{array}$ \\
1 & $\begin{array}{l}\text { Jarang menggunakan pasta } \\
\text { gigi yang mengandung } \\
\text { fluoride \& kumur larutan }\end{array}$ & 0 \\
2 & $\begin{array}{l}\text { yang mengandung fluoride } \\
\text { Hanya menggunakan pasta } \\
\text { gigi yang mengandung } \\
\text { fluoride } \\
\text { Tidak pernah menggunakan } \\
\text { pasta gigi yang mengandung } \\
\text { fluoride \& kumur larutan } \\
\text { yang mengandung fluoride }\end{array}$ & 0 \\
\multicolumn{1}{c}{ Total }
\end{tabular}

Hasil pengukuran ketujuh parameter dari setiap responden dimasukkan ke dalam Kariogram untuk memperoleh tingkat resiko karies pada setiap responden tersebut (Tabel 8). 
Kawung, Wicaksono, Soewantoro; Gambaran Resiko Karies Gigi pada Mahasiswa...

Tabel 8. Tingkat pengukuran resiko karies gigi pada seluruh responden

\begin{tabular}{ccc}
\hline Tingkat resiko karies & $\mathbf{n}$ & $\mathbf{\%}$ \\
\hline Rendah, $>75 \%$ & 52 & 100 \\
Sedang, $25 \%-75 \%$ & 0 & 0 \\
Tinggi, $<25 \%$ & 0 & 0 \\
Total & 52 & 100 \\
\hline
\end{tabular}

\section{BAHASAN}

Hasil penelitian menunjukkan bahwa responden mahasiswa angkatan $2008 \mathrm{di}$ Program Studi Pendidikan Dokter Gigi Fakultas Kedokteran UNSRAT mempunyai skor pengalaman karies gigi (DMF-T) yang rendah.

Tingkat kesadaran mahasiswa angkatan 2008 di Program Studi Pendidikan Dokter Gigi Fakultas Kedokteran UNSRAT sudah sangat baik dalam memelihara kesehatan gigi walaupun sebelum menjadi mahasiswa di Program Studi Pendidikan Dokter Gigi Fakultas Kedokteran Universitas Sam Ratulangi Manado.

Paling sedikit responden yang mengonsumsi jajanan dengan kandungan karbohidrat rendah (11,5\%). Sedangkan responden yang mengonsumsi jajanan dengan kandungan karbohidrat tinggi (32,7\%) menyebabkan karies seperti roti, teh manis, biskuit, minuman berkarbonasi (softdrink), manisan dan responden yang mengonsumsi jajanan dengan kandungan karbohidrat sangat tinggi (36,6\%) menyebabkan karies seperti sirup, permen, es krim, dan coklat lebih banyak dikonsumsi oleh mahasiswa angkatan 2008 di Program Studi Pendidikan Dokter Gigi Fakultas Kedokteran UNSRAT. Penyebabnya mungkin karena teh manis, sirup, softdrink umumnya dikonsumsi mahasiswa saat makan makanan pokok yaitu sarapan, makan siang, atau makan malam. Sebagian besar mahasiswa angkatan 2008 di Program Studi Pendidikan Dokter Gigi Fakultas Kedokteran UNSRAT (78,8\%) mengonsumsi jajanan dengan frekuensi maksimal tiga kali sehari dan hanya sebagian kecil
(21,2\%) dengan frekuensi jajan 4-5 kali sehari di antara jam makan makanan pokok.

Persentase terbesar skor plak pada mahasiswa angkatan 2008 di Program Studi Pendidikan Dokter Gigi Fakultas Kedokteran UNSRAT termasuk kategori baik menurut Löe \& Silness (baik: PI = 0,4 1,0). Hal ini mungkin karena keseluruhan responden mahasiswa angkatan 2008 di Program Studi Pendidikan Dokter Gigi Fakultas Kedokteran UNSRAT menyatakan menggunakan pasta gigi fluoride dalam menjaga dan mempertahankan kesehatan rongga mulut.

Dari hasil penelitian, rata-rata sekresi saliva permenit pada responden mahasiswa angkatan 2008 di Program Studi Pendidikan Dokter Gigi Fakultas Kedokteran UNSRAT termasuk dalam kategori normal dalam parameter Kariogram. Selain itu, kapasitas buffer berdasarkan $\mathrm{pH}$ dengan menggunakan $\mathrm{pH}$ indikator pada mahasiswa angkatan 2008 di Program Studi Pendidikan Dokter Gigi Fakultas Kedokteran UNSRAT termasuk dalam kategori keadaan saliva yang optimal. Dengan kapasitas buffer saliva yang optimal, saliva dapat mengembalikan keadaan di dalam rongga mulut yang asam akibat demineralisasi menjadi normal dengan remineralisasi saliva.

Berdasarkan dari hasil penelitian, terlihat bahwa persentase pengukuran resiko karies gigi pada responden mahasiswa angkatan 2008 di Program Studi Pendidikan Dokter Gigi Fakultas Kedokteran UNSRAT menunjukan bahwa seluruh responden memiliki resiko karies gigi yang rendah dantidak ada responden mahasiswa angkatan 2008 di Program Studi Pendidikan Dokter Gigi Fakultas Kedokteran UNSRAT yang menunjukkan resiko karies gigi yang tinggi.Menurut Bratthall, resiko rendah yang ditunjukkan Kariogram memiliki peluang untuk menghindari karies gigi pada masa mendatang dengan syarat tidak terjadi perubahan skor pada parameter Kariogram. ${ }^{4}$

Untuk memperoleh hasil yang lebih tepat, uji Streptococcus mutans perlu dilakukan untuk memperoleh gambaran resiko karies yang lebih lengkap. Hal ini mungkin disebabkan karena karies adalah 
penyakit multifaktorial dimana bakteri sebagai salah satu penyebabnya. Selain itu, diketahui bahwa Streptococcus mutans merupakan penyebab utama karies. Sedangkan pada penggunaan program fluor, menyikat gigi dengan pasta berfluoride dikombinasi dengan pemakaian obat kumur yang mengandung fluormasih perlu ditingkatkan untuk mencegah pembentukan plak gigi sehingga kesehatan rongga mulut dapat dipertahankan.

\section{SIMPULAN}

Hasil penelitian pada mahasiswa angkatan 2008 di Program Studi Pendidikan Dokter Gigi Fakultas Kedokteran UNSRAT menunjukkan:

1. Seluruh responden menunjukkan skor pengalaman karies yang rendah

2. Sebagian besar responden sangat sering mengonsumsi kandungan jajanan dengan karbohidrat tinggi.

3. Mayoritasrespondenmengonsumsi makanan dengan frekuensi tiga kali dalam satu hari yang termasuk dalam kategori rendah.

4. Mayoritas responden mempunyai skor plak yang termasuk dalam kategori baik.

5. Keseluruhanresponden menyatakan menggunakan pasta gigi mengandung fluoride.

\section{SARAN}

1. Setiap mahasiswa yang telah menjadi responden pada penelitian ini dapat lebih meningkatkan pengetahuan tentang resiko karies gigi dan pencegahannya, mengkonsumsi jajanan yang mampu menghambat karies seperti buah-buahan, sayur-sayuran, susu, dan permen karet yang mengandung xilitol.

2. Perlu dilakukan penelitian lanjutan mengenai tingkat resiko karies gigi pada kalangan masyarakat lainya untuk memperoleh hasil pembanding dengan resiko karies gigi pada mahasiswa angkatan 2008 di Program Studi Pendidikan Dokter Gigi Fakultas Kedokteran UNSRAT.

\section{DAFTAR PUSTAKA}

1. Pintauli S, Hamada $T$, Menuju gigi dan mulut sehat: pencegahan dan pemeliharaan. Medan: USU Press; 2008.h.4-24.

2. Badan Peneliti dan Pengembangan Kesehatan Republik Indonesia: Laporan Hasil Riset Kesehatan Dasar Nasional 2007. Jakarta: Departemen Kesehatan RI, 2008.

3. Panjaitan M.Ilmu pencegahan karies gigi. Kedokteran Gigi UI J; 1997.h.1-5.

4. Nolte WA.Oral microbiology with basic microbiology and immunology. $4^{\text {th }}$ ed. Saint Louis: Mosby; 1982.p.287-9, 304-5, 30910, 336-8. 